\title{
Pengaruh Pemberian Makanan Bayi Dan Anak (PMBA) Sesuai Tahapan Pada Balita Usia 0 - 24 Bulan Dalam Upaya Penurunan Resiko Stunting Pada 1000 Hari Pertama Kehidupan Di Posyandu Wilayah Keja Puskesmas Kereng Bangkirai Kota Palangka Raya Kalimantan Tengah
}

\author{
Desi Kumala ${ }^{1}$, Siti Santy Sianipar ${ }^{2}$ \\ Sekolah Tinggi Ilmu Kesehatan Eka Harap Palangka Raya \\ Korespondensi Penulis. \\ Email: desikumala1287@gmail.com
}

DOI: https://doi.org/10.33859/dksm.v10i2.499

\begin{abstract}
Abstrak
Latar Belakang: Masalah gizi di Indonesia yang menjadi perhatian utama saat ini adalah gizi kurang pada anak balita yang tergolong dalam periode emas 1000 Hari Pertama Kehidupan (HPK). Program 1000 HPK dapat dilihat dari peningkatan status gizi pada bayi dan balita dan penurunan angka stunting. Angka stunting di Indonesia masih relatif tinggi, faktor resiko penyebab stunting di Indonesia kekurangan asupan gizi terutama pada bayi dan balita. Akibatnya menyebabkan meningkatnya resiko kematian, gangguan pertumbuhan fisik dan perkembangan mental (Profil Kesehatan Indonesia, 2016).

Tujuan: Mengetahui Pengaruh Pemberian Makanan Bayi dan Anak (PMBA) sesuai Tahapan pada Balita Usia 0 - 24 Bulan dalam Upaya Penurunan Resiko Stunting pada 1000 Hari Pertama Kehidupan di Posyandu Wilayah Kerja Puskesmas Kereng Bangkirai Kota Palangka Raya.

Metode: Desain penelitian mengunakan Quasi Exsperimen dengan model after and before with control design. Populasi adalah Semua ibu yang memiliki bayi dan anak usia $0-24$ bulan di Posyandu, teknik sampling purposive sampling. Instrumen penelitian digunakan lembar observasi dan Check List. Data yang digunakan data primer. Analisis Data Univariat, Bivariat,Multivariat. Prinsip etik yaitu Beneficence, Respect for Person, Confidentiality Procedures,Justice, Informed Consent.

Hasil: Terdapat pengaruh kenaikan TB dan BB Balita yang signifikan sebelum dan sesudah pendidikan kesehatan Pemberian PMBA, hasil analisis bivariat kelompok penelitian, kelengkapan imunisasi, jumlah anak, pemberian vitamin, berat lahir, ASI Ekslusif, Menu MP-ASI, dan status pekerjaan orang tua dengan kenaikan BB, TB, dan LILA. Variabel yang paling dominan berhubungan dengan kenaikan BB adalah cara pembuatan MPASI. Hasil analisis didapatkan Odds Ratio (OR) dari variabel cara pembuatan MPASI adalah 1,006 artinya balita yang diberikan MPASI dengan cara buatan sendiri akan mempengaruhi kenaikan BB sebesar 1,006 kali lebih tinggi dibandingkan MPASI yang di buat dari bahan instan.

Simpulan: Pendidikan kesehatan cara pembuatan PMBA dapat dijadikan sebagai salah satu intervensi mandiri untuk meningkatkan status gizi pada anak dan penurunan resiko stunting pada bayi dan balita. Berdasarkan hasil penelitian ini diharapkan ibu yang memiliki balita usia 0-24 bulan dapat mempraktekkan secara rutin sehingga dapat meningkatkan pertumbuhan dan perkembangan anak balita.
\end{abstract}

Kata Kunci: PMBA sesuai tahapan, Balita usia 0-24 bulan, Resiko Stunting, 1000 HPK 


\section{Abstract}

Background: Corrupt nutrition in indonesia becomes the main concern now is nutrition lacking in children under five that characterizes the period gold 1000 the first day of life (HPK).The program 1000 HPK can be seen in an increase in the nutritional status on the baby and the toddler and he was the decrease in stunting. Stunting rate in Indonesia is still relatively high, risk factors in indonesia the cause of stunting undernourished especially in infants and children under five. As a result leads to the increasing the risk of death, physical growth and development of mental disorder (Kesehatan Indonesia Indonesia's Health Profile, 2016 )

Purpose: knowing the power feeding infants and children ( pmba) according to the stage in toddlers age 0 until 24 months of effort to reduce the risk stunting on 1000 the first day of life on the work area Posyandu Puskesmas Kereng Bangkirai town Palangka Raya.

Metode : Design study use a quasi exsperimen with a model after and before with control design.The population is all women who have babies and children aged $0-24$ months, sampling purposive sampling technique. Research instruments used sheets observation and check list .The data used primary data. Analysis of data univariat, bivariat, multivariate. The principle of conduct beneficence , respect for person, confidentiality procedures, justice, informed consent.

Results : There is the influence of the increase in $t b$ and $b b$ toddler who significant before and after granting pmba, health education the analysis of, bivariat research groups completeness, immunization the number of children, the provision of vitamin, born, heavy exclusive, breast milk the menu MP-ASI, and the status of a parent job with an increased, BB TB, and LILA.The most dominant variable associated with the increase in bb is a way of making mpasi.The analysis to come by odds ratio ( OR ) of variable method of making mpasi is 1,006 means a toddler given mpasi by artificial means alone will affect the increase in 1,006 BB as much as times higher than mpasi to be made of material instant.

Conclusions: Health education method of making pmba can be used as one of independent intervention to improve the nutritional status in children and a decrease in risk stunting in infants and toddlers.Based on the research is expected that have toddlers mother age 0-24 month can practice regularly so as to increase the growth and development of children under five.

Key words: PMBA, According To The Stage Toddlers 0-24, Age Months The Risk Stunting

\section{PENDAHULUAN}

Masalah gizi di Indonesia menjadi

perhatian utama saat ini adalah masalah kurang

gizi pada anak yang termasuk dalam periode

emas 1000 HPK. 1000 HPK yaitu dimulai dari

270 hari selama kehamilan dan 730 hari pada

kehidupan pertama bayi yang dilahirkan. Pada

1000 HPK gangguan gizi sangat berpengaruh terhadap perkembangan fisik dan kognitif

(Profil Kesehatan Indonesia, 2016). Salah satu

kesempatan emas untuk melakukan

pencegahan kekurangan gizi beserta akibatnya

dengan cara tercukupi status gizi pada bayi dan

balita dan keberhasilan program pemenuhan 
gizi pada bayi dan balita yang masuk dalam 1000 HPK.

Berdasarkan data yang dikutip dari Profil Kesehatan Indonesia tahun 2016 jumlah presentase gizi buruk pada balita usia 0-23 bulan $3,1 \%$ gizi kurang sebesar $11,8 \%$. Balita pendek sebesar $14,6 \%$ dan sangat pendek sebesar 7,1\%. Balita kurus usia 0-23 bulan sebesar $8,9 \%$ dan sangat kurus sebesar 3,7\%. Profil Kesehatan Kalimantan Tengah tahun 2016 kasus gizi buruk 69 kasus. Sedangkan Profil Dinas Kesehatan Kota Palangkaraya tahun 2016 menemukan 3 kasus gizi buruk dari 10,941 balita $(0,03 \%)$ yang ditimbang di puskesmas maupun posyandu. Laporan Penilaian Status Gizi (PSG) balita di Puskesmas Kereng Bangkirai menunjukkan balita dengan sangat kurus $1,5 \%$, gizi kurang $5,6 \%$. Balita sangat pendek $11 \%$, balita pendek 9,6\%. Tahun 2017 Balita sangat kurus 2\% dan balita kurus $4,5 \%$. Data tersebut menunjukkan bahwa pencapaian pemenuhan gizi pada bayi dan balita periode 1000 HPK belum memenuhi target (Profil Kesehatan Kaliamantan Tengan, 2016).
Faktor resiko penyebab stunting di Indonesia yaitu pendidikan orang tua yang mempengaruhi perubahan cara perawatan sehari - hari, termasuk pemberian vitamin A, kelengkapan imunisasi, dan pemberian garam beryodium pada anak. Penelitian Torlesse, $\mathrm{H}(2016)$ menyebutkan faktor risiko terjadinya stunting yaitu anak laki-laki, usia anak, ekonomi rendah, tidak melakukan pemeriksaan kehamilan ke dalam fasilitas kesehatan, sanitasi yang buruk. Dampak Kekurangan gizi terutama pada bayi dan balita menyebabkan tingginya resiko kematian dan terganggunya pertumbuhan fisik dan perkembangan mental. Untuk itu asupan gizi dan cara pemberian makanan yang benar sesuai tahapan sangat penting untuk diperhatikan, untuk keberlangsungan kehidupan, pertumbuhan, perkembangan serta pemenuhan gizi bayi dan balita. 
Dinamika Kesehatan Jurnal Kebidanan dan Keperawatan Vol 10 No. 2 Desember 2019 ( ISSN: 2086-3454 EISSN: 2549-4058)

url: http://ojs.dinamikakesehatan.unism.ac.id DOI: https://doi.org/10.33859/dksm.v10i2

Pengaruh Pemberian Makanan Bayi Dan Anak (Pmba) Sesuai Tahapan Pada Balita Usia 0 - 24 Bulan Dalam Upaya Penurunan Resiko

Stunting Pada 1000 Hari Pertama Kehidupan Di Posyandu Wilayah Keja Puskesmas Kereng Bangkirai Kota Palangka Raya Kalimantan Tengah

\section{METODE}

Desain penelitian mengunakan Quasi Exsperimen dengan model after and before with control design. Populasi adalah Semua ibu yang memiliki bayi dan anak usia $0-24$ bulan di Posyandu Wilayah Kerja Puskesmas Kereng Bangkirai Kota Palangka Raya, teknik sampling purposive sampling. Instrumen penelitian yang digunakan menggunakan lembar observasi dan Check List. Data yang digunakan data primer. Analisis Data Univariat, Bivariat,Multivariat. Prinsip etik yaitu Beneficence, Respect for Person, Confidentiality Procedures,Justice, Informed

\section{Consent.}

\section{HASIL PENETIAN}

\section{Hasil Analis Univariat :}

Tabel 1 Hasil Analisis Univariat Pengaruh Pemberian Makanan Bayi dan Anak (PMBA) sesuai Tahapan pada Balita Usia 0 -24 Bulan

\begin{tabular}{rlrr}
\hline No & \multicolumn{1}{c}{ Variabel } & Frekuensi & $\%$ \\
\hline & Kelompok Penelitian & & \\
1 & Kel. intervensi & 52 & 50,0 \\
& Kelo. kontrol & 52 & 50,0 \\
& $\begin{array}{l}\text { Berat badan (BB) anak sebelum } \\
\text { tindakan }\end{array}$ & \\
& Tidak naik & 50 & 48,1 \\
2 & Naik & 54 & 51,9 \\
& Berat badan (BB) anak sesudah & \\
& tindakan & & \\
& Tidak naik & 40 & 38,5 \\
3 & Naik & 64 & 61,5 \\
& Lingkar lengan atas anak sebelum & \\
& tindakan & & \\
& $<14,75 \mathrm{~cm}$ & 46 & 44,2 \\
& $>14,75$ & 58 & 55,8 \\
\hline
\end{tabular}

\begin{tabular}{|c|c|c|c|}
\hline \multirow{4}{*}{5} & \multicolumn{3}{|c|}{$\begin{array}{l}\text { Lingkar lengan atas anak sesudah } \\
\text { tindakan }\end{array}$} \\
\hline & $<14,75 \mathrm{~cm}$ & 40 & 38,5 \\
\hline & $>14,75$ & 64 & 61,5 \\
\hline & \multicolumn{3}{|c|}{ Tinggi badan anak sebelum tindakan } \\
\hline \multirow{2}{*}{6} & Pendek & 20 & 19,2 \\
\hline & Normal & 84 & 80,8 \\
\hline \multirow{4}{*}{7} & \multicolumn{3}{|c|}{ Tinggi badan anak sesudah tindakan } \\
\hline & Pendek & 22 & 21,2 \\
\hline & Normal & 82 & 78,8 \\
\hline & Kelengkapan imunisasi & & \\
\hline \multirow{3}{*}{8} & Tidak lengkap & 35 & 33,7 \\
\hline & Lengkap & 69 & 66,3 \\
\hline & Saudara & & \\
\hline \multirow{3}{*}{9} & 3 orang & 40 & 38,5 \\
\hline & $<3$ orang & 64 & 61,5 \\
\hline & Pemberian vitamin & & \\
\hline \multirow{3}{*}{10} & Tidak diberikan & 39 & 37,5 \\
\hline & Diberikan & 65 & 62,5 \\
\hline & ASI ekslusif & & \\
\hline \multirow{3}{*}{11} & Tidak ekslusif & 28 & 26,9 \\
\hline & Ekslusif & 76 & 73,1 \\
\hline & Makanan pendamping ASI & IPAS & \\
\hline \multirow{3}{*}{12} & Instant & 32 & 30,8 \\
\hline & Buatan & 72 & 69,2 \\
\hline & Riwayat berat lahir anak & & \\
\hline \multirow{3}{*}{13} & BBLR & 30 & 28,8 \\
\hline & Normal & 74 & 71,2 \\
\hline & Status pekerjaan orang tua & & \\
\hline \multirow{3}{*}{14} & Swasta & 69 & 66,3 \\
\hline & PNS & 35 & 33,7 \\
\hline & Total & 104 & 100,0 \\
\hline
\end{tabular}

Berdasarkan tabel 5.1 analisis univariat Pengaruh Pemberian Makanan Bayi dan Anak (PMBA) sesuai Tahapan pada Balita Usia $0-24$ Bulan dalam Upaya Penurunan Resiko Stunting pada 1000 Hari Pertama Kehidupan di Posyandu Wilayah Keja Puskesmas Kereng Bangkirai Kota Palangka Raya dapat di simpulkan bahwa dari 104 responden kelompok penelitian $52(50 \%)$ 
Dinamika Kesehatan Jurnal Kebidanan dan Keperawatan Vol 10 No. 2 Desember 2019 ( ISSN: 2086-3454 EISSN: 2549-4058)

url: http://ojs.dinamikakesehatan.unism.ac.id DOI: https://doi.org/10.33859/dksm.v10i2

Pengaruh Pemberian Makanan Bayi Dan Anak (Pmba) Sesuai Tahapan Pada Balita Usia 0 - 24 Bulan Dalam Upaya Penurunan Resiko

Stunting Pada 1000 Hari Pertama Kehidupan Di Posyandu Wilayah Keja Puskesmas Kereng Bangkirai Kota Palangka Raya Kalimantan Tengah

reponden, kelompok kontrol 52 (50\%), BB

anak sebelum dilakukan penelitian terdapat kenaikan $54(51,9 \%)$ responden, BB setelah dilakukan penelitian terdapat kenaikan 64 $(61,5 \%)$ responden, LILA > 14,75 sebelum penelitian $58(55,8 \%)$ responden, LILA > 14,75 setelah penelitian $64(61,5 \%)$ responden, TB sebelum penelitian normal $84(80,8 \%)$ responden, TB setelah penelitian normal 82 (78,8\%) responden, imunisasi lengkap 69 $(66,3 \%)$ responden, jumlah saudara $<3$ orang $64(61,5 \%)$, pemberian vitamin tambahan diberikan $65(62,5 \%)$ responden, pemberian ASI Eksklusif $76(73,1 \%)$ responden, cara pembuatan MPASI buatan sendiri $72(69,2 \%)$ responden, riwayat berat lahir anak normal 74 $(71,2 \%)$ responden, dan status pekerjaan orang tua $69(66,3 \%)$ responden.

\section{Hasil Analis Bivariat :}

Tabel 2 Analisis Bivariat Pengaruh Pemberian PMBA pada Balita Usia 0-24 Bulan sebelum dan sesudah diberikan Pendidikan Kesehatan dengan kenaikan Berat Badan (BB), Tinggi Badan (TB), Lingkar lengan atas (LILA)

\begin{tabular}{cccc}
\hline $\begin{array}{c}\text { Berat badan anak } \\
\text { sesudah tindakan } \\
\text { - Berat badan } \\
\text { anak sebelum } \\
\text { tindakan }\end{array}$ & $\begin{array}{c}\text { Lingkar lengan } \\
\text { atas anak sesudah } \\
\text { tindakan - Lingkar } \\
\text { lengan atas anak } \\
\text { sebelum tindakan }\end{array}$ & $\begin{array}{c}\text { Tinggi badan } \\
\text { anak sesudah } \\
\text { tindakan - Tinggi } \\
\text { badan anak } \\
\text { sebelum tindakan }\end{array}$ \\
\hline P Value & .050 & .014 & .527 \\
\hline
\end{tabular}

Berdasarkan tabel 5.2 dapat disimpulkan bahwa uji pengaruh menggunakan Mc-Nemar test Pemberian PMBA sesuai tahapan pada Balita Usia 0-24 Bulan : pada kenaikan BB $p$ value $=0,050$ artinya terdapat pengaruh yang signifikan sebelum dan sesudah pendidikan kesehatan tentang Pemberian PMBA sesuai tahapan pada Balita Usia 0-24 Bulan di Puskesmas Kereng Bangkirai kota Palangka Raya Kalimantan Tengah. Kenaikan TB $p$ value $=0,014$ artinya terdapat pengaruh yang signifikan sebelum dan sesudah pendidikan kesehatan tentang Pemberian PMBA sesuai tahapan pada Balita Usia 0-24 Bulan di Puskesmas Kereng Bangkirai kota Palangka Raya Kalimantan Tengah. Sedangkan kenaikan LILA $p$ value $=0,527$ artinya tidak ada pengaruh yang signifikan sebelum dan sesudah pendidikan kesehatan tentang Pemberian PMBA sesuai tahapan pada Balita Usia 0-24 Bulan di Puskesmas Kereng Bangkirai kota Palangka Raya Kalimantan Tengah. 
Dinamika Kesehatan Jurnal Kebidanan dan Keperawatan Vol 10 No. 2 Desember 2019 ( ISSN: 2086-3454 EISSN: 2549-4058)

url: http://ojs.dinamikakesehatan.unism.ac.id DOI: https://doi.org/10.33859/dksm.v10i2

Pengaruh Pemberian Makanan Bayi Dan Anak (Pmba) Sesuai Tahapan Pada Balita Usia 0 - 24 Bulan Dalam Upaya Penurunan Resiko

Stunting Pada 1000 Hari Pertama Kehidupan Di Posyandu Wilayah Keja Puskesmas Kereng Bangkirai Kota Palangka Raya Kalimantan Tengah

\section{Hasil Analisis Multivariat}

Tabel 6 Analisis Multivariat Faktor - faktor yang mempengaruhui Pemberian PMBA pada Balita Usia 0-24 Bulan dengan kenaikan Berat Badan (BB)

\begin{tabular}{|c|c|c|c|c|c|}
\hline \multicolumn{6}{|c|}{ Pemodelan I } \\
\hline & & \multirow[t]{2}{*}{ Sig. } & \multirow[t]{2}{*}{$\operatorname{Exp}(B)$} & \multicolumn{2}{|c|}{ 95\% C.I.for $\operatorname{EXP}(\mathrm{B})$} \\
\hline & & & & Lower & Upper \\
\hline \multirow[t]{13}{*}{ Step 1} & Imunisasi & ,664 & 1,222 & ,494 & 3,022 \\
\hline & Kelompo & ,397 & ,695 &, 300 & 1,613 \\
\hline & $\mathrm{k}$ & & & & \\
\hline & MPASI &, 174 &, 513 & , 196 & 1,344 \\
\hline & Anak &, 113 & 2,046 &, 844 & 4,955 \\
\hline & Vitamin & ,856 & 1,084 & ,456 & 2,574 \\
\hline & Asi_eksl &, 574 & 1,312 & ,509 & 3,382 \\
\hline & usif & & & & \\
\hline & BB_lahir &, 253 &, 561 & ,209 & 1,509 \\
\hline & _anak & & & & \\
\hline & Status_pe & ,486 & 1,381 &, 557 & 3,420 \\
\hline & kerjaan & & & & \\
\hline & Constant & ,438 & 1,868 & & \\
\hline \multicolumn{6}{|c|}{ Pemodelan II } \\
\hline & & \multirow[t]{2}{*}{ Sig. } & \multirow[t]{2}{*}{$\operatorname{Exp}(B)$} & \multicolumn{2}{|c|}{ 95\% C.I.for $\operatorname{EXP}(\mathrm{B})$} \\
\hline & & & & Lower & Upper \\
\hline \multirow[t]{4}{*}{ Step 2} & Imunisasi &, 053 & 2,377 & ,988 & 5,717 \\
\hline & Kelompok & ,061 & ,445 & ,191 & 1,039 \\
\hline & MPASI &, 051 & ,373 & , 138 & 1,006 \\
\hline & Constant & ,076 & 2,862 & & \\
\hline
\end{tabular}

a. Ternyata setelah ftv keluar, perubahan OR untuk semua variabel yg Tersisa tidak ada yang $>10 \%$. Dengan demikian ASI Eksklusif, Status Pekerjaan, Riwayat Lahir Anak, Jumlah anak, sehingga variabel tersebut di keluarkan dari pemodelan dikeluarkan dari Model. Selanjutnya variabel umur dicoba dikeluarkan dari model

b. Dari analisis multivariat ternyata variabel yang berhubungan bermakna dengan kenaikan BB adalah kelengkapan

imunisasi dan cara pembuatan MP ASI

sedangkan kelompok penelitian sebagai

variabel pengontrol /konfounding.

Variabel yang paling dominan

berhubungan dengan kenaikan BB adalah

cara pembuatan MPASI. Hasil analisis

didapatkan Odds Ratio (OR) dari variabel

cara pembuatan MPASI adalah 1,006

artinya balita yang diberikan MPASI

dengan cara buatan sendirii akan

mempengaruhi kenaikan $\mathrm{BB}$ sebesar

1,006 kali lebih tinggi dibandingkan

MPASI yang di bikin dari bahan instan.

Tabel 7 Analisis Multivariat Faktor - faktor yang mempengaruhui Pemberian PMBA pada Balita Usia 0-24 Bulan dengan kenaikan Lingkar Lengan Atas (LILA)

\begin{tabular}{|ll|r|r|r|r|}
\hline & Sig. & Exp(B) & \multicolumn{2}{c|}{$95 \%$ C.I.for } \\
& & & & \multicolumn{2}{c|}{ EXP(B) } \\
\cline { 5 - 6 } & &, 049 & 2,567 & 1,005 & 6,553 \\
Step 1 & Imunisasi &, 118 &, 495 &, 205 & 1,197 \\
& Kelompok &, 421 &, 687 &, 275 & 1,714 \\
& Status_pekerjaan &, 032 &, 317 &, 111 &, 904 \\
MPASI &, 407 & 1,481 &, 586 & 3,746 \\
Anak &, 191 &, 498 &, 175 & 1,416 \\
BB_lahir_anak &, 323 & 1,649 &, 612 & 4,448 \\
Asi_ekslusif &, 165 & 2,973 & & \\
Constant & &
\end{tabular}


a. Dari hasil analisis terlihat ada 8 variabel yang $\mathrm{p}$ valuenya $>0,05$ yaitu semua variabel di keluarkan dari pemodelan namun di lihat segi substansi 2 variabel yang sangat mempengaruhi kenaikan LILA pada balita yaitu kelompok penelitian dan jumlah anak, untuk itu variabel kelompok penelitian dan anak dimasukkan kembali kedalam pemodelan.

\begin{tabular}{|c|r|r|r|r|}
\hline & \multicolumn{1}{|c|}{ Pemodelan II } \\
\cline { 4 - 5 } & Sig. & \multirow{2}{*}{ Exp(B) } & 95\% C.I.for EXP(B) \\
\cline { 4 - 6 } & & & \multicolumn{1}{l|}{ Lower } & Upper \\
\hline Step 1a Kelompok &, 270 &, 635 &, 284 & 1,422 \\
Anak &, 159 & 1,799 &, 795 & 4,070 \\
Constant &, 371 & 1,421 & & \\
\hline
\end{tabular}

Dari analisis multivariat ternyata tidak ada variabel yang berhubungan bermakna dengan kenaikan LILA. Hasil analisis didapatkan memiliki Odds Ratio (OR) dari Jumlah anak adalah 4,070 artinya balita yang jumlah anak $<3$ anak akan mempengaruhi kenaikan LILA sebesar 4,070 kali lebih tinggi dibandingkan $>3$ anak
Tabel 8 Analisis Multivariat Faktor - faktor yang mempengaruhui Pemberian PMBA pada Balita Usia 0-24 Bulan dengan kenaikan Tinggi Badan (TB)

\begin{tabular}{|c|c|c|c|c|c|}
\hline & & \multirow[t]{2}{*}{ Sig. } & \multirow[t]{2}{*}{$\operatorname{Exp}(B)$} & \multicolumn{2}{|c|}{$\begin{array}{c}\text { 95\% C.I.for } \\
\operatorname{EXP}(\mathrm{B}) \\
\end{array}$} \\
\hline & & & & Lower & Upper \\
\hline Step & Kelompok & ,071 & 2,777 & ,916 & 8,423 \\
\hline \multirow[t]{8}{*}{1} & Anak & ,907 & 1,068 & ,358 & 3,188 \\
\hline & Imunisasi & ,152 & ,425 & ,132 & 1,371 \\
\hline & Vitamin & ,034 & ,267 & ,079 & ,902 \\
\hline & Asi_ekslusif & ,327 &, 542 & , 159 & 1,848 \\
\hline & MPASI & ,462 & 1,527 & ,494 & 4,723 \\
\hline & BB_lahir_anak &, 503 & ,646 &, 180 & 2,315 \\
\hline & Status_pekerjaan & ,020 & ,269 & ,089 &, 811 \\
\hline & Constant & ,003 & 28,331 & & \\
\hline
\end{tabular}

a. Dari hasil analisis terlihat ada 5 variabel yang $\mathrm{p}$ valuenya $>0,05$ yaitu jumlah anak, cara pembuatan MPASI, ASI Eksklusif, Riwayat lahir anak, kelengkapan imunisasi. Sehingga variabel tersebut di keluarkan dari pemodelan

b.

\section{Pemodelan II}

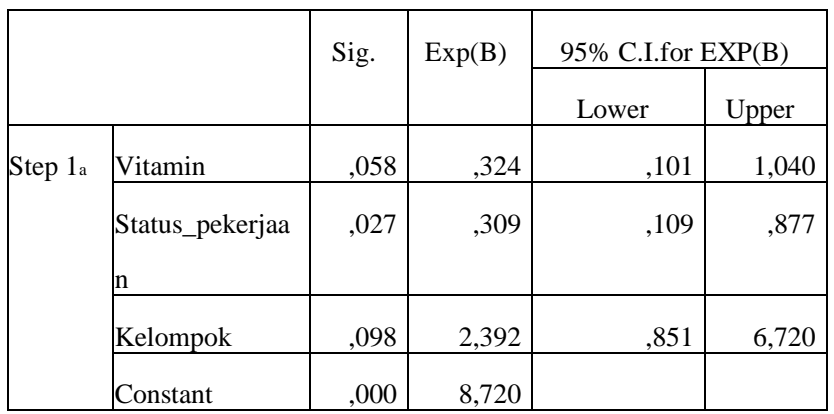

Dari analisis multivariat ternyata variabel yang berhubungan bermakna dengan kenaikan TB adalah status pekerjaan orang tua dan pemberian vitamin pada balita sedangkan kelompok penelitian sebagai variabel pengontrol /confounding. Variabel yang 
Dinamika Kesehatan Jurnal Kebidanan dan Keperawatan Vol 10 No. 2 Desember 2019 ( ISSN: 2086-3454 EISSN: 2549-4058)

url: http://ojs.dinamikakesehatan.unism.ac.id DOI: https://doi.org/10.33859/dksm.v10i2

Pengaruh Pemberian Makanan Bayi Dan Anak (Pmba) Sesuai Tahapan Pada Balita Usia 0 - 24 Bulan Dalam Upaya Penurunan Resiko

Stunting Pada 1000 Hari Pertama Kehidupan Di Posyandu Wilayah Keja Puskesmas Kereng Bangkirai Kota Palangka Raya Kalimantan Tengah

paling dominan berhubungan dengan

kenaikan TB adalah status pekerjaan orang

tua. Hasil analisis didapatkan Odds Ratio

(OR) dari variabel status pekerjaan orang tua adalah 0,877 artinya balita yang status pekerjaan orang tua swasta dengan akan mempengaruhi kenaikan TB sebesar 0,877 kali lebih tinggi dibandingkan orang tua yang bekerja sebagai PNS.

\section{PEMBAHASAN}

\section{Hasil Analisis Univariat tentang} Pemberian Makanan Bayi dan Anak (PMBA) sesuai Tahapan pada Balita Usia 0 - 24 Bulan

Berdasarkan tabel 1 analisis univariat Pengaruh Pemberian Makanan Bayi dan Anak (PMBA) sesuai Tahapan pada Balita Usia $0-24$ Bulan dalam Upaya Penurunan Resiko Stunting pada 1000 Hari Pertama Kehidupan di Posyandu Wilayah Keja Puskesmas Kereng Bangkirai Kota Palangka Raya dapat di simpulkan bahwa dari 52 responden kelompok penelitian $52(50 \%)$ reponden, kelompok kontrol 52 (50\%), BB anak sebelum dilakukan penelitian terdapat kenaikan $54(51,9 \%)$ responden, BB setelah dilakukan penelitian terdapat kenaikan 64
$(61,5 \%)$ responden, LILA > 14,75 sebelum penelitian $58(55,8 \%)$ responden, LILA > 14,75 setelah penelitian $64(61,5 \%)$ responden, TB sebelum penelitian normal $84(80,8 \%)$ responden, TB setelah penelitian normal 82 (78,8\%) responden, imunisasi lengkap 69 $(66,3 \%)$ responden, jumlah saudara $<3$ orang $64(61,5 \%)$, pemberian vitamin tambahan diberikan $65(62,5 \%)$ responden, pemberian ASI Eksklusif $76(73,1 \%)$ responden, cara pembuatan MPASI buatan sendiri $72(69,2 \%)$ responden, riwayat berat lahir anak normal 74 $(71,2 \%)$ responden, dan status pekerjaan orang tua $69(66,3 \%)$ responden.

Menurut Chomaria (2014) MP-ASI merupakan peralihan asupan yang semata berbasis susu menuju ke makanan yang semi padat. Pemberian makan yang tidak tepat dapat mengakibatkan anak mengalami malnutrisi, gizi buruk, kecerdasan otak tidak maksimal, menurunkan daya tahan tubuh dan pertumbuhan serta perkembangan terhambat. Pemberian makan yang tepat pada bayi dan anak dapat mempengaruhi kenaikan berat badan secara optimal sehingga anak dapat 
Dinamika Kesehatan Jurnal Kebidanan dan Keperawatan Vol 10 No. 2 Desember 2019 ( ISSN: 2086-3454 EISSN: 2549-4058)

url: http://ojs.dinamikakesehatan.unism.ac.id DOI: https://doi.org/10.33859/dksm.v10i2

Pengaruh Pemberian Makanan Bayi Dan Anak (Pmba) Sesuai Tahapan Pada Balita Usia 0 - 24 Bulan Dalam Upaya Penurunan Resiko

Stunting Pada 1000 Hari Pertama Kehidupan Di Posyandu Wilayah Keja Puskesmas Kereng Bangkirai Kota Palangka Raya Kalimantan Tengah

mengalami pertumbuhan dan berkembangan dengan sehat dan baik. Teguh,dkk, 2015 menyatakan hal yang sama Hasil analisa menggunakan uji chi square didapatkan bahwa $\rho=0,000<0,05$ yang artinya ada hubungan pola pemberian MP-ASI dengan pertumbuhan bayi usia $6-12$ bulan. Pola pemberian MP-ASI yang sesuai akan membuat pertumbuhan bayi naik dan Pola pemberian MP-ASI yang tidak sesuai akan membuat pertumbuhan bayi tidak naik. Sebagai ibu lebih aktif mencari informasi tentang MP- ASI yang bervariasi sesuai dengan tahapan usia bayi.

Berdasarkan fakta dan teori diatas, terdapat kesamaan antara hasil penelitian Penelitian Chomaria, 2014 dan Teguh,dkk, 2015 sesuai dengan hasil penelitian yang di lakukan di Posyandu Puskesmas Kereng Bangkirai pada analisis univariat pada tabel 5.1 dari hasil penelitian tersebut dapat disimpulkan bahwa kelompok kontrol yang tidak diberikan intervensi mengenai pentingnya Pemberian Makanan Bayi dan Anak (PMBA) sesuai Tahapan pada Balita Usia 0 - 24 Bulan kenaikan BB, TB, LILA setelah dilakukan pengamatan dan pengukuran selama 3 bulan kenaikannya tidak menentu, bahkan sebagian besar anak balita tidak mengalami kenaikan sama sekali. Berbeda dengan anak pada kelompok intervensi setelah dilakukan pendidikan kesehatan tentang pemberian makanan tambahan yang tepat sesuai tahapan, kenaikan BB, TB, LILA dapat di lihat perubahannya pada pengukuran bulan berikutnya. Diharapkan kepada orang tua bayi, terutama ibu untuk memberikan makanan tambahan kepada bayi tidak hanya untuk memberika rasa kenyang pada bayi tetapi juga memperhatikan kandungan gizi pada makanan, sehingga makanan yang dikonsumsi dapat memberikan nutrisi pada bayi dan pertumbuhan anak dapat berkembang sesuai dengan umurnya.

\section{Hasil Analisis Bivariat tentang Pemberian Makanan Bayi dan Anak (PMBA) sesuai Tahapan pada Balita Usia 0 - 24 Bulan}

Berdasarkan tabel 2 dapat disimpulkan bahwa uji pengaruh menggunakan Mc-Nemar test Pemberian PMBA sesuai tahapan pada Balita Usia 0-24 Bulan : pada kenaikan BB $p$ 
Dinamika Kesehatan Jurnal Kebidanan dan Keperawatan Vol 10 No. 2 Desember 2019 ( ISSN: 2086-3454 EISSN: 2549-4058)

url: http://ojs.dinamikakesehatan.unism.ac.id DOI: https://doi.org/10.33859/dksm.v10i2

Pengaruh Pemberian Makanan Bayi Dan Anak (Pmba) Sesuai Tahapan Pada Balita Usia 0 - 24 Bulan Dalam Upaya Penurunan Resiko

Stunting Pada 1000 Hari Pertama Kehidupan Di Posyandu Wilayah Keja Puskesmas Kereng Bangkirai Kota Palangka Raya Kalimantan Tengah

value $=0,050$ artinya terdapat pengaruh yang signifikan sebelum dan sesudah pendidikan kesehatan tentang Pemberian PMBA sesuai tahapan pada Balita Usia 0-24 Bulan di Puskesmas Kereng Bangkirai kota Palangka Raya Kalimantan Tengah. Kenaikan TB $p$ value $=0,014$ artinya terdapat pengaruh yang signifikan sebelum dan sesudah pendidikan kesehatan tentang Pemberian PMBA sesuai tahapan pada Balita Usia 0-24 Bulan di Puskesmas Kereng Bangkirai kota Palangka Raya Kalimantan Tengah. Sedangkan kenaikan LILA $p$ value $=0,527$ artinya tidak ada pengaruh yang signifikan sebelum dan sesudah pendidikan kesehatan tentang Pemberian PMBA sesuai tahapan pada Balita Usia 0-24 Bulan di Puskesmas Kereng Bangkirai kota Palangka Raya Kalimantan Tengah.

Penelitian Ade Rahmawati,2018 juga menyatakan hal yang sama bahwa Berdasarkan hasil dari uji paired $T$ test diperoleh nilai $p$ value 0,000 kurang dari 0,05 , sehingga ada perbedaan efek pendidikan kesehatan sebelum da sesudah pemberian makanan pendamping air susu ibu terhadap kenaikan berat badan pada balita di wilayah kerja Puskesmas Juntinyuat. Penelitian Agus, 2017 menyebutkan hasil penelitian yang dilakukan menunjukan hubungan signifikan antara pemberian ASI $(p=0,000, O R=21,0)$ dan pemberian MP-ASI $(\mathrm{p}=0,006, \quad \mathrm{OR}=6,5)$ dengan pertumbuhan bayi $6-24$ bulan. Rendahnya pemberian ASI eksklusif dan kurang baiknya pemberian MP-ASI berhubungan dengan banyaknya anak yang tidak dapat tumbuh secara normal. Disarankan, perlu dilakukan konseling dan penyuluhan secara komprehensif oleh tenaga kesehatan untuk meningkatkan pemberian ASI eksklusif dan MP-ASI.

Berdasarkan fakta dan teori diatas terdapat kesamaan dengan hasil penelitian yang dilakukan di Posyandu Puskesmas Kereng Bangkirai yaitu terdapat pengaruh yang signifikan sebelum dan sesudah pendidikan kesehatan tentang Pemberian PMBA sesuai tahapan pada Balita Usia 0-24 Bulan di Puskesmas Kereng Bangkirai kota Palangka Raya Kalimantan Tengah pada kenaikan TB 
Dinamika Kesehatan Jurnal Kebidanan dan Keperawatan Vol 10 No. 2 Desember 2019 ( ISSN: 2086-3454 EISSN: 2549-4058)

url: http://ojs.dinamikakesehatan.unism.ac.id DOI: https://doi.org/10.33859/dksm.v10i2

Pengaruh Pemberian Makanan Bayi Dan Anak (Pmba) Sesuai Tahapan Pada Balita Usia 0 - 24 Bulan Dalam Upaya Penurunan Resiko

Stunting Pada 1000 Hari Pertama Kehidupan Di Posyandu Wilayah Keja Puskesmas Kereng Bangkirai Kota Palangka Raya Kalimantan Tengah

dan BB Balita, namun tidak ada pengaruh pada

kenaikan ukuran LILA. Sedangkan definisi

stunting menurut Kementerian Kesehatan

(Kemenkes) adalah anak balita dengan nilai z-

scorenya kurang dari -2SD/standar deviasi

(stunted) dan kurang dari - 3SD (severely

stunted). Walaupun tidak ada pengaruh

terhadap kenaikan LILA Balita dengan adanya

perubahan kenaikan pada TB, BB sudah

menunjukkan perubahan Gizi pada Balita.

Oleh karena itu Peranan tenaga kader

posyandu terampil sangat besar terhadap

keberhasilan Pemberian makanan bayi dan

Anak (PMBA), peningkatan pemberdayaan

ibu, peningkatan dukungan anggota keluarga

serta peningkatan kualitas makanan bayi dan

anak yang akan meningkatkan status gizi balita

(Millennium Challenge Account - Indonesia,

2013)

3. Hasil analisis multivariat faktor yang dominan mempengaruhi kenaikan BB,TB,BB sebelum dan setelah di berikan Pendidikan Kesehatan

Hasil analisis multivariat ternyata

variabel yang berhubungan bermakna dengan

kenaikan BB adalah kelengkapan imunisasi

dan cara pembuatan MP ASI sedangkan kelompok penelitian sebagai variabel

pengontrol/confounding. Variabel yang paling dominan berhubungan dengan kenaikan $\mathrm{BB}$ adalah cara pembuatan MPASI. Hasil analisis didapatkan Odds Ratio (OR) dari variabel cara pembuatan MPASI adalah 1,006 artinya balita yang diberikan MPASI dengan cara buatan sendirii akan mempengaruhi kenaikan BB sebesar 1,006 kali lebih tinggi dibandingkan MPASI yang di bikin dari bahan instan

Penelitian Firlia, 2017 menyatakan bahwa hasil penelitian menunjukkan perbedaan signifikan antara skor pengetahuan dan perilaku pemberian MPASI pada sebelum dan sesudah penyuluhan pada kelompok perlakuan dan kelompok kontrol (p: < 0.05). Terdapat perbedaan skor pengetahuan yang signifikan setelah pemberian penyuluhan dan pelatihan MP-ASI antara kelompok perlakuan dan kelompok kontrol (p:0.011) namun tidak terdapat perbedaan skor perilaku antara kelompok perlakuan dan kelompok kontrol baik pada sebelum maupun sesudah perlakuan. Peningkatan skor pengetahuan lebih baik pada kelompok yang diberikan penyuluhan dengan 
Dinamika Kesehatan Jurnal Kebidanan dan Keperawatan Vol 10 No. 2 Desember 2019 ( ISSN: 2086-3454 EISSN: 2549-4058)

url: http://ojs.dinamikakesehatan.unism.ac.id DOI: https://doi.org/10.33859/dksm.v10i2

Pengaruh Pemberian Makanan Bayi Dan Anak (Pmba) Sesuai Tahapan Pada Balita Usia 0 - 24 Bulan Dalam Upaya Penurunan Resiko

Stunting Pada 1000 Hari Pertama Kehidupan Di Posyandu Wilayah Keja Puskesmas Kereng Bangkirai Kota Palangka Raya Kalimantan Tengah

Modul MP-ASI dan Pelatihan pembuatan MP-

ASI. Berat badan digunakan untuk memonitor

pertumbuhan anak apabila ada masalah dapat

diketahui sejak awal sehingga pencegahan dan

penanganan dapat segera dilakukan. Anak

yang mendapatkan nutrisi yang adekuat tidak

dapat dipastikan bahwa anak tumbuh dan

berkembang dengan baik, apalagi jika nutrisi

yang diterima anak tidak adekuat maka dapat

menghambat anak mencapai derajat kesehatan

yang optimal (Purwitasari, 2009). hal-hal yang

harus diperhatikan dalam pemberian makan

pada bayi dan anak yang meliputi usia anak,

frekuensi pemberian makanan dalam sehari,

jumlah pemberian makanan atau porsi untuk

sekali makan, tekstur makanan, variasi

makanan, memberikan makanan secara aktif/

responsive pada anak dan selalu menjaga

kebersihan (Silawati, dkk, 2013).

Pemberian makan yang tidak tepat dapat mengakibatkan anak mengalami

malnutrisi, gizi buruk,kecerdasan otak tidak maksimal, menurunkan daya tahan tubuh dan pertumbuhan serta perkembangan terhambat. Pemberian makan yang tepat pada bayi dan anak dapat mempengaruhi kenaikan berat badan secara optimal sehingga anak dapat mengalami pertumbuhan dan berkembangan dengan sehat dan baik. PMBA yaitu memberikan air susu ibu (ASI) kepada bayi segera dalam waktu 30 menit setelah bayi lahir, memberikan ASI saja atau pemberian ASI secara eksklusif sejak lahir sampai bayi berusia 6 bulan, memberikan makanan pendamping air susu ibu (MPASI) sejak bayi berusia 6 bulan sampai 24 bulan serta meneruskan pemberian ASI sampai anak berusia 24 bulan atau lebih. Teori dan fakta di atas memiliki kesamaan pada hasil penelitian cara pembuatan PMBA yang tepat dan pemberiannya sesuai dapat meningkatkan kenaikan berat badan. Sehingga kecukupan gizi anak dapat tercukupi. Adapun kelengkapan imunisasi merupakan sarana pelindung meningkatkan kesehatan anak.

Tabel 7 Dari analisis multivariat ternyata tidak ada variabel yang berhubungan bermakna dengan kenaikan LILA. Hasil analisis didapatkan memiliki Odds Ratio (OR) dari Jumlah anak adalah 4,070 artinya balita 
yang jumlah anak $<3$ anakakan mempengaruhi kenaikan LILA sebesar 4,070 kali lebih tinggi dibandingkan $>3$ anak.

Hasil penelitian Stefani,dkk,2013 menyatakan bahwa Berdasarkan hasil uji chisquare didapatkan tidak ada hubungan bermakna antara jumlah saudara dan perkembangan anak $(\mathrm{p}=0,128)$. Hasil penelitian ini tidak sejalan dengan teori yang menyatakan jumlah anak yang banyak pada keluarga dapat menyebabkan kurangnya perhatian dan kasih sayang yang diterima anak. Suasana emosional dalam rumah, sangat merangsang perkembangan otak anak yang sedang tumbuh dan mengembangkan kemampuan mentalnya. Jadi, hasil penelitian tidak bermakna mungkin disebabkan oleh pemerataan pemenuhan kebutuhan kasih sayang dan perhatian sehingga setiap aspek perkembangan dapat berjalan dengan baik.

Penelitian Rona Firmana Putri, 2015 menyebutkan Berdasarkan analisis bivariat didapatkan pendidikan ibu $(\mathrm{p}=0,022)$, pekerjaan ibu $(\mathrm{p}=0,000)$, pendapatan keluarga $(\mathrm{p}=0,012)$, jumlah anak $(\mathrm{p}=0,008)$ dan pola asuh ibu $(\mathrm{p}=0,000)$. Sementara dari analisis multivariat didapatkan pendidikan ibu $(\mathrm{p}=0,004 ; \quad \mathrm{OR}=2,594 ; \mathrm{CI} 95 \%=1,356-4,963)$, pekerjaan $\quad$ ibu $\quad(p=0,000 ; \quad O R=74,769$; CI95\% $=24,141-231,577), \quad$ pendapatan keluarga $(\mathrm{p}=0,013 ; \mathrm{OR}=3,058$; CI95\%=1,246$7,4)$ dan pola asuh ibu ( $\mathrm{p}=0,000 ; \mathrm{OR}=15,862$; CI95\% $=5,973-42,128) . \quad$ Analisis bivariat menunjukan bahwa terdapat hubungan antara pendidikan ibu, pekerjaan ibu, pendapatan keluarga, jumlah anak dan pola asuh ibu dengan status gizi anak balita. Berdasarkan hasil analisis multivariat faktor pekerjaan ibu merupakan faktor paliang paling berhubungan dengan status gizi anak.

Tabel 8 Dari analisis multivariat ternyata variabel yang berhubungan bermakna dengan kenaikan TB adalah status pekerjaan orang tua dan pemberian vitamin pada balita sedangkan kelompok penelitian sebagai variabel pengontrol /konfounding. Variabel yang paling dominan berhubungan dengan kenaikan TB adalah status pekerjaan orang tua. Hasil analisis didapatkan Odds Ratio (OR) dari variabel status pekerjaan orang tua adalah 
0,877 artinya balita yang status pekerjaan

orang tua swasta dengan akan mempengaruhi

kenaikan TB sebesar 0,877 kali lebih tinggi

dibandingkan orang tua yang bekerja sebagai

PNS.

\section{SARAN}

Pendidikan kesehatan tentang cara pembuatan PMBA dapat dijadikan sebagai salah satu intervensi mandiri untuk meningkatkan status gizi pada anak dan penurunan resiko stunting pada bayi dan balita Berdasarkan hasil penelitian ini diharapkan ibu yang memiliki balita usia 0-24 bulan dapat mempraktekkan secara rutin sehingga dapat meningkatkan pertumbuhan dan perkembangan anak balita.

\section{UCAPAN TERIMA KASIH}

1. RISTEKDIKTI yang telah memberikan bantuan kepada peneliti untuk melakukan penelitian

2. Semua pihak yang membantu kegiatan penelitian mulai pengumpulan data, pengolahan data, analisa data hingga kegiatan seminar akhir berjalan dengan lancar

\section{DAFTAR REFERENSI}

\section{Depkes RI. 2010. Strategi Peningkatan}

Makanan Bayi dan Anak (PMBA). Kementrian Kesehatan. Jakarta
ISPC. (2017). Golden Age. Jakarta: PT. International Services Pacific Cross.

Kementrian Kesehatan RI. (2014). Pelatihan Konseling Pemberian Makan Bayi dan Anak ( PMBA ). Jakarta: Millennium Challenge Account - Indonesia

Kusumawati, E., Rahardjo, S., Sari, H. P., Kesehatan, J., Fakultas, M., Universitas, I. K., \& Soedirman, J. (2013). Model Pengendalian Faktor Risiko Stunting pada Anak Usia di Bawah Tiga Tahun Model of Stunting Risk Factor Control among Children under Three Years, 249-256.

Millennium Challenge Account - Indonesia. (2013). Stunting dan Masa Depan Indonesia (Vol. 2010). Jakarta: Millennium Challenge Account Indonesia.

Purwitasari, Desi dan Dwi Maryanti. 2009. Gizi dalam Kesehatan Reproduksi. Yogyakarta: Nuha Medika

Sekertariat Wakil Presiden RI. (2017). 100 Kabupaten/Kota Prioritas untuk Intervensi Anak Kerdil (Stunting). Jakarta: Tim Nasional Percepatan Penanggulangan Kemiskinan.

Silawati, dkk.2013. Kegiatan Pemberian Makanan pada Bayi dan Anak (PMBA) dalam Situasi Bencana. Jakarta: Departemen Komunikasi World Vision Indonesia.

Suhardjo. 2010. Pemberian Makanan pada Bayi dan Anak. Yogyakarta: Kanisius

Trihono Atmarita, dkk. (2015). Pendek (Stunting) di Indonesia, Masalah dan Solusinya. Jakarta: Badan Penelitian dan Pengembangan Kesehatan 
Dinamika Kesehatan Jurnal Kebidanan dan Keperawatan Vol 10 No. 2 Desember 2019 ( ISSN: 2086-3454 EISSN: 2549-4058)

url: http://ojs.dinamikakesehatan.unism.ac.id DOI: https://doi.org/10.33859/dksm.v10i2

Pengaruh Pemberian Makanan Bayi Dan Anak (Pmba) Sesuai Tahapan Pada Balita Usia 0 - 24 Bulan Dalam Upaya Penurunan Resiko Stunting Pada 1000 Hari Pertama Kehidupan Di Posyandu Wilayah Keja Puskesmas Kereng Bangkirai Kota Palangka Raya Kalimantan Tengah 